\title{
Viruses: agents of coral disease?
}

\author{
S. K. Davy ${ }^{1,2,4, *}$, S. G. Burchett ${ }^{1,2}$, A. L. Dale ${ }^{1,3,5}$, P. Davies ${ }^{1,2,6}$, J. E. Davy ${ }^{1,7}$, \\ C. Muncke ${ }^{1,2,7,8}$, O. Hoegh-Guldberg ${ }^{7}$, W. H. Wilson ${ }^{1,6}$ \\ ${ }^{1}$ Marine Biological Association of the UK, Citadel Hill, Plymouth PL1 2PB, UK \\ ${ }^{2}$ Institute of Marine Studies, University of Plymouth, Drake Circus, Plymouth PL4 8AA, UK \\ ${ }^{3}$ School of Biological Sciences, University of Plymouth, Drake Circus, Plymouth PL4 8AA, UK

\begin{abstract}
${ }^{4}$ Present address: School of Biological Sciences, Victoria University of Wellington, PO Box 600, Wellington, New Zealand Cork, Ireland

${ }^{6}$ Present address: Plymouth Marine Laboratory, Prospect Place, The Hoe, Plymouth PL1 3DH, UK

${ }^{7}$ Present address: Centre for Marine Studies, University of Queensland, Brisbane QLD 4072, Australia

${ }^{8}$ Present address: EM Unit, School of Biomedical Sciences, Nuffield Building, University of Liverpool, Crown Street,
\end{abstract} \\ ${ }^{5}$ Present address: Department of Zoology, Ecology and Plant Science, University College Cork, Lee Maltings, Prospect Row, \\ Liverpool L69 3BX, UK
}

\begin{abstract}
The potential role of viruses in coral disease has only recently begun to receive attention. Here we describe our attempts to determine whether viruses are present in thermally stressed corals Pavona danai, Acropora formosa and Stylophora pistillata and zoanthids Zoanthus sp., and their zooxanthellae. Heat-shocked P. danai, A. formosa and Zoanthus sp. all produced numerous virus-like particles (VLPs) that were evident in the animal tissue, zooxanthellae and the surrounding seawater; VLPs were also seen around heat-shocked freshly isolated zooxanthellae (FIZ) from $P$. danai and $S$. pistillata. The most commonly seen VLPs were tail-less, hexagonal and about 40 to $50 \mathrm{~nm}$ in diameter, though a diverse range of other VLP morphotypes (e.g. rounded, rod-shaped, droplet-shaped, filamentous) were also present around corals. When VLPs around heat-shocked FIZ from $S$. pistillata were added to non-stressed FIZ from this coral, they resulted in cell lysis, suggesting that an infectious agent was present; however, analysis with transmission electron microscopy provided no clear evidence of viral infection. The release of diverse VLPs was again apparent when flow cytometry was used to enumerate release by heat-stressed A. formosa nubbins. Our data support the infection of reef corals by viruses, though we cannot yet determine the precise origin (i.e. coral, zooxanthellae and/or surface microbes) of the VLPs seen. Furthermore, genome sequence data are required to establish the presence of viruses unequivocally.
\end{abstract}

KEY WORDS: Viruses $\cdot$ Corals $\cdot$ Zooxanthellae $\cdot$ Coral disease $\cdot$ Coral health $\cdot$ Stress Resale or republication not permitted without written consent of the publisher

\section{INTRODUCTION}

There is currently a huge international effort to determine the causative agents and environmental triggers of coral disease, prompted by ever more frequent reports of disease episodes and novel disease types (e.g. Harvell et al. 1999, 2002, Barber et al. 2001, Porter et al. 2001, Sutherland et al. 2004). To date, coral disease agents identified include various bacteria (Kushmaro et al. 2001, Cooney et al. 2002, Cervino et al. 2004), cyanobacteria (Harvell et al. 2001, Cooney et al. 2002, Richardson \& Kuta 2003), fungi (Geiser et al.
1998, Alker et al. 2001) and trematodes (Aeby 2003), but one group of pathogens, the viruses, was first considered only recently (Wilson et al. 2001) and deserves greater attention.

In the past 10 to 15 years, the importance of viruses in marine systems has become increasingly clear. Virioplankton densities have been estimated to be in the order of $10^{6}$ to $10^{8} \mathrm{ml}^{-1}$, which is about 5 to 25 times higher than for bacterial densities (Bergh et al. 1989, Fuhrman 1999), while the diversity of marine viruses is now thought to be considerable (e.g. Chen et al. 1996). Furthermore, the ecological importance of viruses in 
the world's oceans appears to be far greater than was first supposed, as viruses not only have the potential to infect most marine organisms (Fuhrman 1999), but also play a pivotal role in the structuring of planktonic communities (Suttle 1994, Hennes et al. 1995, Jacquet et al. 2002, Wilson et al. 2002a, b, Schroeder et al. 2003), biogeochemical cycling (Fuhrman 1999), biogas production (Malin et al. 1998), and the mediation of horizontal gene transfer (Jiang \& Paul 1998). Given this widespread ecological importance, it would not be surprising if viruses also play a central role in the health of reef corals and their symbiotic dinoflagellates (zooxanthellae); indeed it would be more of a surprise if viruses played no role at all. Moreover, key triggers of viral propagation and infection include elevated temperature (Edgar \& Lielausis 1964), UV light (Jacquet \& Bratbak 2003) and the availability of nutrients (Scanlan \& Wilson 1999), all of which have been implicated either in coral disease outbreaks (Israely et al. 2001, Bruno et al. 2003, Nowak 2004) or coral bleaching events (reviewed by Douglas 2003, Hoegh-Guldberg 2004, Lesser 2004).

Given the above, we first used the common European sea anemone Anemonia viridis to test our hypothesis that latent viruses, present within the host cnidarian and/or its zooxanthellae, enter a lytic cycle when environmentally stressed (by heat or UV light) and so kill their host organism (Wilson et al. 2001). Our data provided strong evidence for this, as virus-like particles (VLPs: the term used for particles of viral appearance whose infectivity and chemical structure have not yet been established; Leadbeater et al. 1998) were seen with transmission electron microscope (TEM) analysis of heat- and UV-stressed isolates of zooxanthellae. Furthermore, when the medium from around these stressed and degenerating zooxanthellae was added to non-stressed zooxanthellae, it induced cell lysis at a similar rate to that seen during thermal stress. These encouraging findings, plus the fact that zooxanthellae in A. viridis are taxonomically similar to those found in reef corals (Bythell et al. 1997, Savage et al. 2002), led to our recent work on the Indo-Pacific scleractinian coral Pavona danai (Wilson et al. 2005). Here, we again used TEM to determine the presence of VLPs before and after thermal stress, and observed a range of VLP types in both coral tissue and the algal symbionts; we also observed similar VLPs in the coral Acropora formosa and the zoanthid Zoanthus sp. after heat shock. Further evidence has recently been provided by Cervino et al. (2004), who reported VLPs in zooxanthellae isolated from the Caribbean reef coral Montastraea sp. when exposed to either elevated temperature or bacterial pathogens.

These TEM observations of VLPs in zooxanthellate sea anemones, zoanthids and scleractinian corals, as well as in the non-symbiotic temperate sea anemone Metridium senile (Wilson \& Chapman 2001) lead to several key questions concerning viral identity, origin, infection patterns, and whether viruses are seen in the field (Wilson et al. 2005). Clearly, the most pressing question is whether or not the VLPs observed to date are actually viruses at all, or just an artefact of the methods employed. Only once the involvement of viruses is proved unequivocally can we begin to assess their true importance to the health of the world's coral reefs. In the present study we draw together a number of preliminary attempts by our research group to characterize the VLPs seen in corals, and highlight the difficulties of both carrying out such work and of interpreting the findings.

\section{MATERIALS AND METHODS}

Experimental organisms. Three species of IndoPacific coral, Pavona danai, Acropora formosa and Stylophora pistillata, and 1 species of Indo-Pacific zoanthid Zoanthus sp, were employed. P. danai, A. formosa and Zoanthus sp. were obtained from commercial aquarist Plymouth Tropical Marine (Plympton) and held in a holding tank at 25 to $28^{\circ} \mathrm{C}$ in artificial seawater (ASW) made using Kent Synthetic Seasalt (Kent Marine) at salinity 33 ppt. Coral nubbins were illuminated from above by a Colorlite $400 \mathrm{~W}$ metal halide lamp on a $7 \mathrm{~h}: 17 \mathrm{~h}$ light:dark cycle (though the light regime was variable as the tank was situated next to a north facing window) and fed regularly with Liquifry Marine for Filter Feeders (Interpet). S. pistillata was collected from the reef flat at Heron Island on the southern Great Barrier Reef and transported to the Centre for Marine Studies, University of Queensland. Here, S. pistillata nubbins were held in a tank at $24^{\circ} \mathrm{C}$ in ASW made using BIO-SEA Marinemix (Aqua Craft) at salinity 35 ppt. S. pistillata nubbins were illuminated from above by 150 W metal halide lamps (MR16 Solux Daylight Dichroic, Lamp Technology International) at 65 to $74 \mu \mathrm{mol}$ photons $\mathrm{m}^{-2} \mathrm{~s}^{-1}$ on a $10 \mathrm{~h}: 14 \mathrm{~h}$ light:dark cycle.

TEM analysis of released VLPs. One major problem with characterizing VLPs in corals and other symbiotic cnidarians is the harvesting of such particles in isolation from their animal or zooxanthella hosts. To determine whether this is possible, we thermally stressed both freshly isolated zooxanthellae (FIZ) and whole coral nubbins or zoanthid polyps, and determined whether VLPs were released into the surrounding seawater using TEM.

Zooxanthellae were isolated from Pavona danai and Acropora formosa using an electric toothbrush and ASP8-A ASW medium (Blank 1987), followed by centrifugation at $3000 \mathrm{rpm}(2000 \times g)$ for 4 to $5 \mathrm{~min}$ and 
re-suspension; this was repeated at least 3 times. Zooxanthellae were isolated from $S$. pistillata using a waterpik and ASW. The resulting slurry was then filtered through a series of plankton nets (mesh sizes 100, 60 and $45 \mu \mathrm{m}$, respectively) to remove skeletal fragments, ciliates and other 'large' micro-organisms, centrifuged for $5 \mathrm{~min}$ at $2500 \mathrm{rpm}(1400 \times g)$ and re-suspended in F/2-medium (Guillard 1975). Sterile laboratory equipment was used in all cases, while isolation media were sterile filtered and/or sterilized with antibiotics.

FIZ from Pavona danai, Acropora formosa and Stylophora pistillata were then exposed to elevated temperatures. FIZ were incubated in tubes containing either ASP8-A or $\mathrm{F} / 2$ media (as above), at 33 to $34^{\circ} \mathrm{C}$ to induce a bleaching response or 25 to $26^{\circ} \mathrm{C}$ in the case of controls. Incubations were either under a $12 \mathrm{~h}: 12 \mathrm{~h}$ light:dark cycle or under a natural light regime (in the case of FIZ from $S$. pistillata only) and lasted for between 24 and $96 \mathrm{~h}$. At the end of incubation, FIZ suspensions were either fixed immediately with $1 \%(\mathrm{v} / \mathrm{v})$ glutaraldehyde (for zooxanthellae from $S$. pistillata only) or centrifuged as before, to pellet the zooxanthellae; this pellet was then fixed in $3 \%$ glutaraldehyde (v/v) and decalcified in $2 \%$ formic acid for $72 \mathrm{~h}$ to remove any skeletal debris. All zooxanthellae were subsequently preserved in osmic acid for up to $1 \mathrm{~h}$, critically point dried through an acetone series to $100 \%$ acetone and embedded in Spurr's resin. Thin sections (50 to $100 \mathrm{~nm}$ ) were cut on a Reichert-Jung ultracut microtome, placed on grids, stained with saturated solutions of uranyl acetate and lead citrate, and analysed by TEM (JEOL model JEM 1010, 1200EXII or JEM 200CX at 80 to $100 \mathrm{kV}$ ). Samples of the medium surrounding the zooxanthellae were prepared for TEM analysis by filtering through a $0.2 \mu \mathrm{m}$ syringe filter to remove zooxanthellae, bacteria and debris. Filtered samples were then either centrifuged onto a TEM grid for $1 \mathrm{~h}$ at $25000 \mathrm{rpm}(50150 \times g)($ Beckman L8-M ultracentrifuge) or a single drop $(\sim 20 \mu \mathrm{l})$ placed directly onto a TEM grid, left for up to $2 \mathrm{~h}$ and the excess liquid removed with filter paper. The samples were then stained and analysed as before.

To determine whether VLPs were released from whole corals, nubbins of Pavona danai were thermally stressed by placing each nubbin in about $70 \mathrm{ml}$ sterile, natural offshore seawater from the English Channel $\left(50^{\circ} 13.79^{\prime} \mathrm{N} 4^{\circ} 9.59^{\prime} \mathrm{W}\right)$ that had been pre-filtered through a $50 \mathrm{kDa}$ polyethersulfone tangential flow filter (Sartorius) to remove bacteria and viruses. Nubbins were heat-shocked by incubating at $32^{\circ} \mathrm{C}$ in a cooled illuminated incubator for $48 \mathrm{~h}$ on a $12 \mathrm{~h}: 12 \mathrm{~h}$ light:dark cycle; control nubbins were held for the same period at $25^{\circ} \mathrm{C}$, again on a $12 \mathrm{~h}: 12 \mathrm{~h}$ light:dark cycle. At the end of the incubation period, seawater samples from around the corals were passed through a $0.2 \mu \mathrm{m}$ filter.
They were then concentrated using a tangential flow Vivaflow $^{\circledR}$ system (Sartorius), centrifugation through a $50 \mathrm{kDa}$ paddle filter (Pall Gelman) at $6240 \times g$ (Megafuge 1.0R, Heraeus Sepatech) and polyethylene glycol (PEG) precipitation, before being analysed using TEM as described above. Furthermore, to determine whether VLPs could be seen in and around coral tissue, nubbins were fixed overnight in $3 \%$ glutaraldehyde (v/v) and decalcified in $2 \%$ formic acid (v/v), before thin sections were prepared as described above and then analysed by TEM; thin sections of polyps from the zoanthid Zoanthus sp. were also analysed after heat shock at $32^{\circ} \mathrm{C}$ for $24 \mathrm{~h}$ (procedure otherwise as for $P$. danai).

Infectivity of released VLPs. Zooxanthellae were isolated from Stylophora pistillata and heat-shocked at $33^{\circ} \mathrm{C}$ for $24 \mathrm{~h}$ under natural light; controls were kept at $25^{\circ} \mathrm{C}$. The zooxanthellar suspension was then passed through a $0.2 \mu \mathrm{m}$ filter and an aliquot $(50 \mu \mathrm{l})$ of the filtrate added to FIZ, also from $S$. pistillata. The inoculated FIZ were held at $25^{\circ} \mathrm{C}$ (i.e. they were not heat-shocked) in a cooled illuminated incubator on a $10 \mathrm{~h}: 14 \mathrm{~h}$ light:dark cycle for $6 \mathrm{~d}$. The density of zooxanthellae (cells ml ${ }^{-1}$ ) was estimated at 1, 2, 3, 5 and $6 \mathrm{~d}$ by counting under a light microscope using a haemacytometer. Thin-sectioning and TEM were used as described above to establish whether the inoculated FIZ contained VLPs .

Flow cytometry analysis of VLP release. Flow cytometry (FC) is a high throughput technique that allows rapid quantification of different types of viruses based on analysis of scatter plots of side-scatter versus fluorescence (following the addition of the nucleic acid stain SYBR Green I) (eg. Brussaard et al. 2000). Here we employed FC to determine the extent to which VLPs were released from thermally stressed (and visibly bleaching) Acropora formosa at a series of time points. TEM analysis of the surrounding seawater was also conducted at each time point (see 'TEM analysis of released VLPs' for methods), both to add to our data from Pavona danai and to relate the physical appearance of any VLPs to the FC data.

More specifically, nubbins of Acropora formosa were each put in containers with enough ASW to cover them, and were then incubated at $34^{\circ} \mathrm{C}$ in a cooled illuminated incubator on a $12 \mathrm{~h}: 12 \mathrm{~h}$ light:dark cycle; controls were maintained in a similar incubator, but at $26^{\circ} \mathrm{C}$. Water samples $(1 \mathrm{ml})$ were collected at the start of the incubation and thereafter at $24 \mathrm{~h}$ intervals; the water in the containers was replaced after each sample was taken, to maintain the health of the corals. The samples were fixed in $0.5 \%$ glutaraldehyde (EM grade, Sigma) and stored overnight at $4^{\circ} \mathrm{C}$. They were then snap frozen in liquid nitrogen and stored at $-80^{\circ} \mathrm{C}$ until FC analysis. 
All FC analyses were conducted using a Becton Dickinson FACScan ${ }^{\mathrm{TM}}$ flow cytometer equipped with an air-cooled laser providing $15 \mathrm{MW}$ at $488 \mathrm{~nm}$ with a standard filter setup. For virus and bacteria analysis/ enumeration, fixed frozen samples were defrosted at room temperature and diluted 10- to 100-fold in TE buffer (10 mM Tris-HCl pH 7.5, 1 mM EDTA) (prefiltered through a $50 \mathrm{kDa}$ VivaFlow 50 'flip-flow' system [Sartorius] then autoclaved). Diluted samples were heated at $80^{\circ} \mathrm{C}$ for $10 \mathrm{~min}$ in the dark (for viruses) or room temperature for $15 \mathrm{~min}$ in the dark (for bacteria) in the presence of SYBR Green I (Molecular Probes) at a final concentration of $10^{-4}$ of the commercial dilution. Samples were analysed by FC for 2 min at a delivery

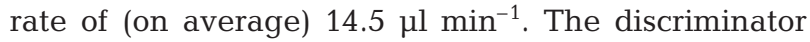
was set to green fluorescence and the detection threshold was adjusted to cut out most of the instrument noise from the blank (10 kDa-filtered seawater diluted 10-fold with TE buffer containing SYBR Green I). Data analysis was carried out using CellQuest ${ }^{\mathrm{TM}}$ v3.3 software (Becton Dickinson), and scatter-plots of side-scatter versus green fluorescence with log amplification on a 4-decade scale were used to discriminate different virus and bacteria groups.

\section{RESULTS}

\section{TEM analysis of released VLPs}

After heat shock, VLPs were seen in and around Zoanthus sp. (Fig. 1) and Pavona danai (Fig. 2A,B), and FIZ from $P$. danai (Fig. 2C); they were also seen around
FIZ from Stylophora pistillata (Fig. 2D) and around nubbins of Acropora formosa (Fig. 2E-G), though not in or around FIZ from this latter coral. The majority of VLPs seen were hexagonal, often in clumps and 40 to $50 \mathrm{~nm}$ in diameter (Figs. 1 \& 2A-C,F). Of particular note, such VLPs were common throughout zooxanthellae and animal tissues, as well as in the surrounding medium. However, some hexagonal VLPs (e.g. those seen in the medium around FIZ from $S$. pistillata, Fig. 2D) were larger (about $80 \mathrm{~nm}$ in diameter), while other VLP forms were also observed around $A$. formosa that were not seen elsewhere. These included rounded VLPs (100 to150 nm in diameter), rod-shaped VLPs (about $200 \mathrm{~nm}$ in length), droplet-shaped VLPs (120 to $150 \mathrm{~nm}$ in length; Fig. 2E) seen on just one occasion, and very long filamentous VLPs (often as long as $3 \mu \mathrm{m}$; Fig. 2G) frequently observed following thermal stress. VLPs were not quantified by TEM analysis, but casual observations suggested that they were far more numerous after nubbins or polyps were heat-shocked than when they were maintained at control temperatures; VLPs were only rarely observed in FIZ controls.

\section{Infectivity of released VLPs}

The medium around heat-shocked FIZ from Stylophora pistillata had a marked effect on the survivorship of FIZ held at non-stressful temperatures (Fig. 3), with a density decrease of about $90 \%$ seen over the $6 \mathrm{~d}$ after inoculation. In contrast, control FIZ declined at about half this rate, which is not surprising for

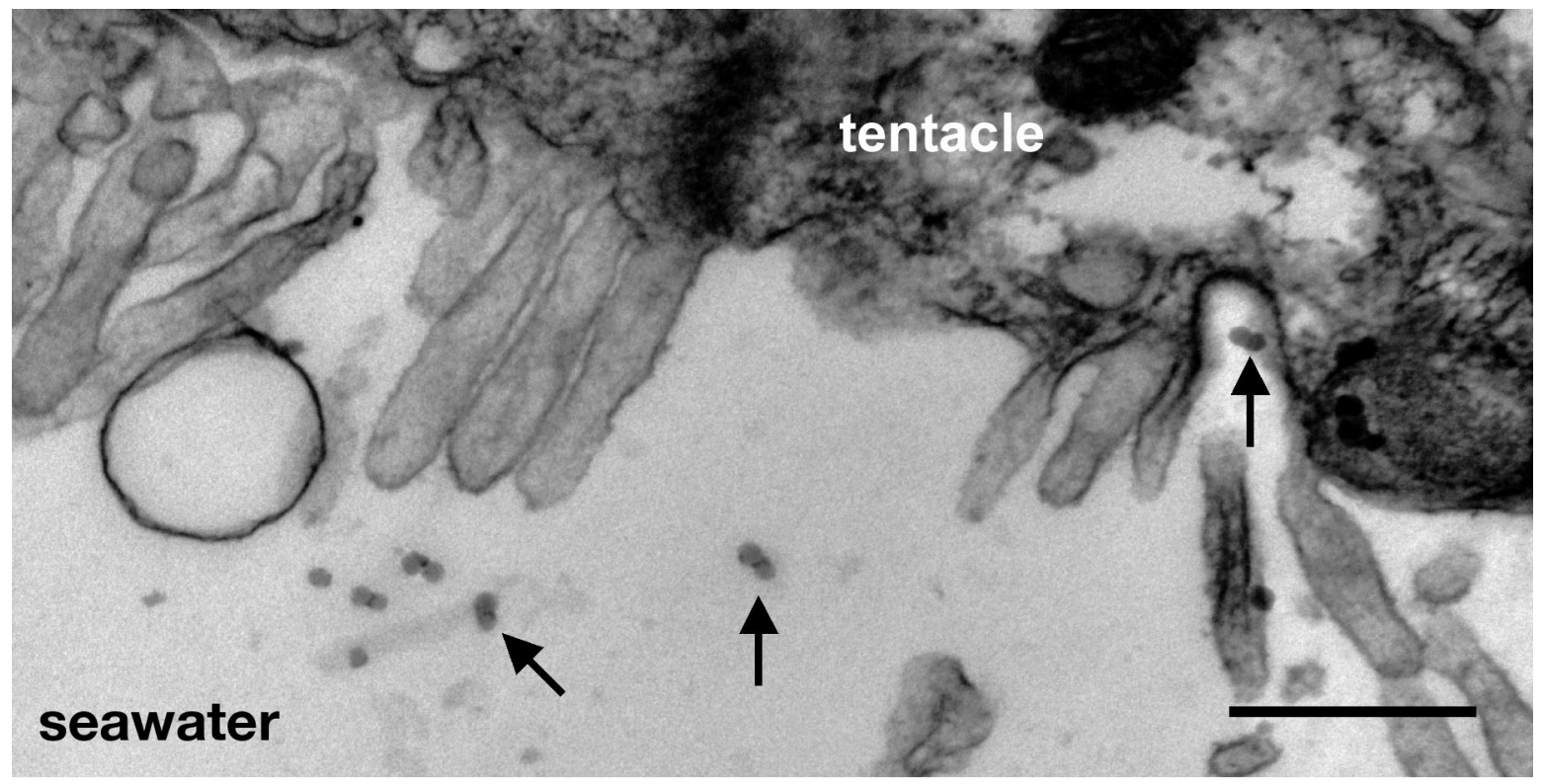

Fig. 1. Zoanthus sp. Virus-like particles (VLPs; arrows) around tentacle of zoanthid after thermal shock. Scale bar $=500 \mathrm{~nm}$ 

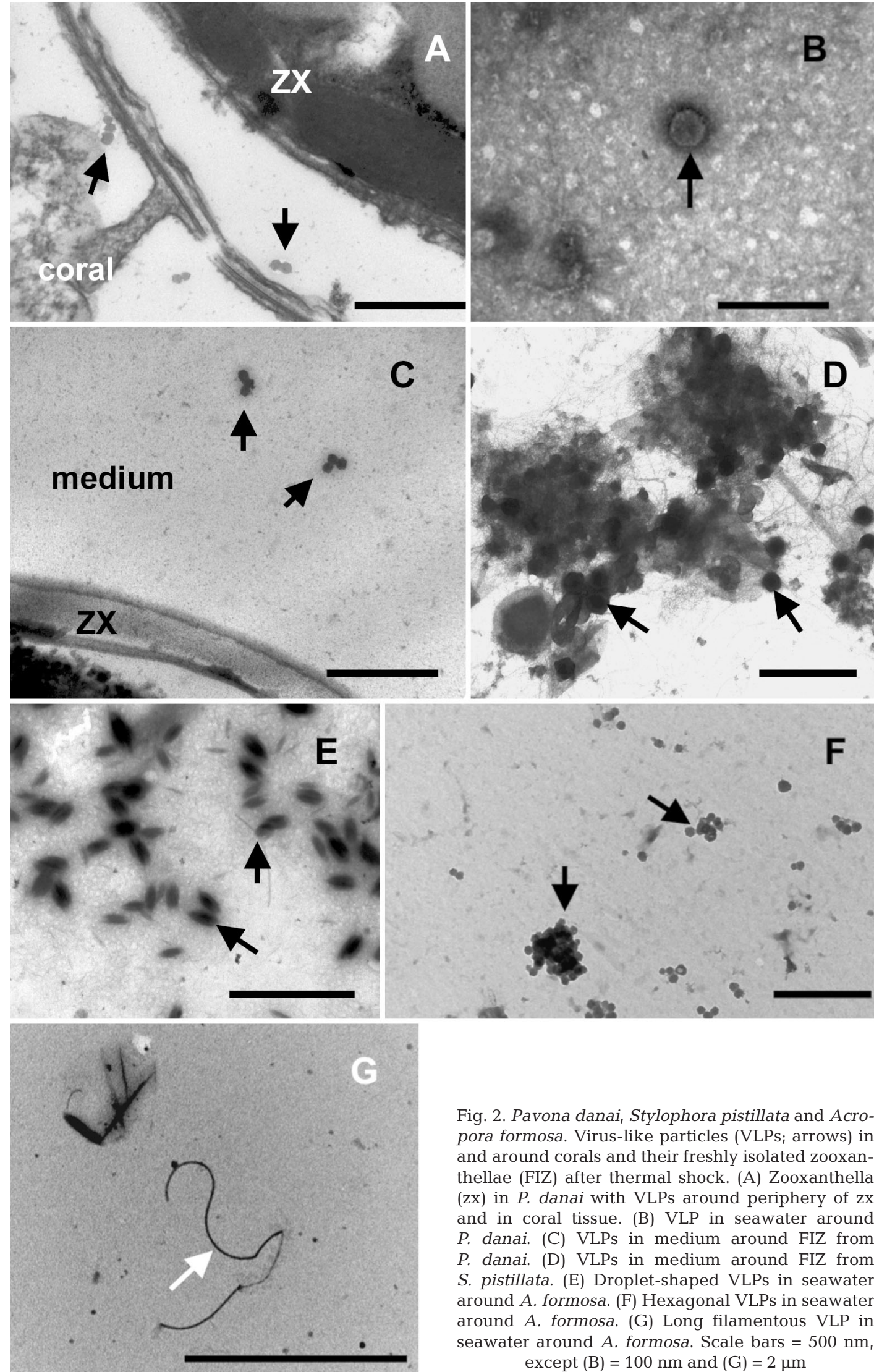

Fig. 2. Pavona danai, Stylophora pistillata and Acropora formosa. Virus-like particles (VLPs; arrows) in and around corals and their freshly isolated zooxanthellae (FIZ) after thermal shock. (A) Zooxanthella (zx) in $P$. danai with VLPs around periphery of $\mathrm{zx}$ and in coral tissue. (B) VLP in seawater around $P$. danai. (C) VLPs in medium around FIZ from P. danai. (D) VLPs in medium around FIZ from S. pistillata. (E) Droplet-shaped VLPs in seawater around $A$. formosa. (F) Hexagonal VLPs in seawater around A. formosa. (G) Long filamentous VLP in seawater around $A$. formosa. Scale bars $=500 \mathrm{~nm}$ except $(B)=100 \mathrm{~nm}$ and $(\mathrm{G})=2 \mu \mathrm{m}$ 


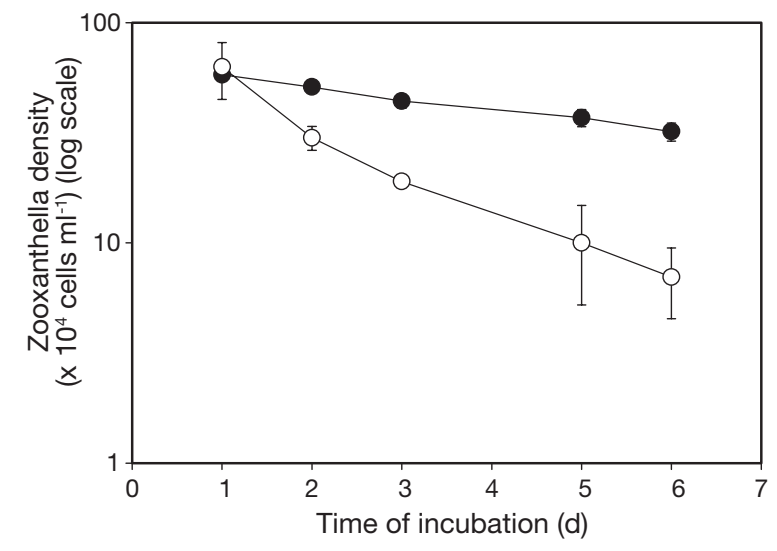

Fig. 3. Stylophora pistillata. Density (mean $\pm \mathrm{SD}, \mathrm{n}=3$ ) of freshly isolated zooxanthellae (FIZ) when incubated with medium from around heat-shocked FIZ (O). Incubations kept at $25^{\circ} \mathrm{C}$ and not thermally stressed. Controls $(\bullet)$ incubated in filtered seawater only second experiment. Again, this virus group was not observed around pre-heat shock corals (Fig. 4C) or around non-heat shock controls (data not shown, but resemble Fig. 4C). TEM analysis of samples collected during the second experiment revealed several long filamentous VLPs (eg. Fig. 2G); however, many other morphotypes were also observed, and no VLP group dominated the TEM images.

\section{DISCUSSION}

Data presented here are from a disparate set of experiments carried out periodically over the last $4 \mathrm{yr}$. We have found it extremely difficult to draw firm conclusions from individual experiments, since data are difficult to repeat and often contradict previous work. zooxanthellae removed from their host cell environment. TEM failed to reveal any obvious VLPs in the inoculated FIZ.

\section{Flow cytometry analysis of VLP release}

Nubbins of Acropora formosa were heat-shocked and bleached, and the size and density of particles present in the surrounding seawater assessed by FC analysis. Two individual experiments were conducted, several months apart. During the first experiment a very distinct group was observed in the region where viruses would be expected (Fig. 4B), $48 \mathrm{~h}$ after the initial heat shock.

This group was not observed around pre-heat shock corals (Fig. 4A) or at any time around non-heat shock controls (data not shown but resemble Fig. 4A). There were approximately $2 \times 10^{7}$ virus particles $\mathrm{ml}^{-1}$ in this group, an order of magnitude higher than the bacteria concentration. In the second experiment, a different batch of $A$. formosa was used and the increase in viruses was followed over time (Fig. 4C-E). Intriguingly, a different group of viruses was observed which had higher fluorescence and sidescatter signals, indicative of the release of a much larger virus. Although the virus concentrations were similar to the previous experiment $\left(3.5 \times 10^{7}\right.$ virus particles $\mathrm{ml}^{-1}$ ) bacteria concentrations were higher than viruses $32 \mathrm{~h}$ after heat shock in the
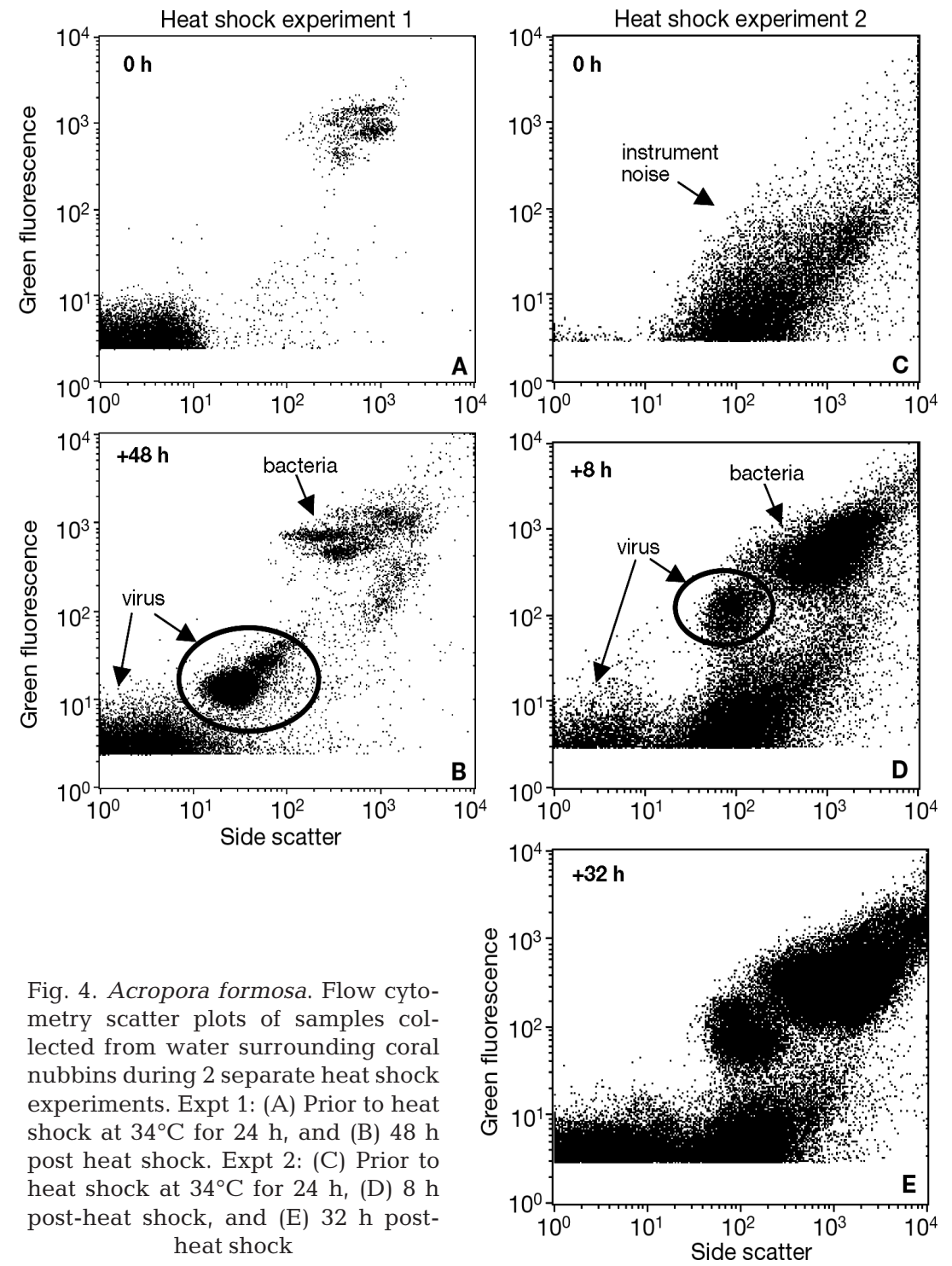

Fig. 4. Acropora formosa. Flow cytometry scatter plots of samples collected from water surrounding coral nubbins during 2 separate heat shock experiments. Expt 1: (A) Prior to heat shock at $34^{\circ} \mathrm{C}$ for $24 \mathrm{~h}$, and (B) $48 \mathrm{~h}$ post heat shock. Expt 2: (C) Prior to heat shock at $34^{\circ} \mathrm{C}$ for $24 \mathrm{~h}$, (D) $8 \mathrm{~h}$ post-heat shock, and (E) $32 \mathrm{~h}$ postheat shock

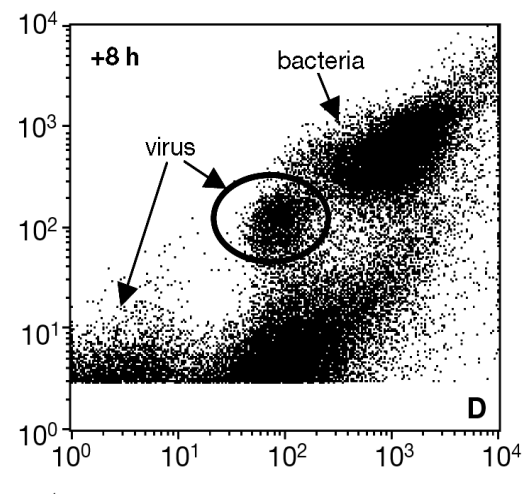


This is the nature of conducting microbiology or virology on coral systems that have been brought into the laboratory where no 2 sets of associated contaminating microbial communities are likely to be the same. We have attempted to summarise results from a few different experiments where the evidence points to (at the very least) the presence of a virus pathogen. What is not clear from our research is what the hosts of these virus pathogens are.

Our previous work (Wilson et al. 2001, 2005, Wilson \& Chapman 2001) has presented numerous TEM images of VLPs in corals, sea anemones and zooxanthellae. In the present study we have furthered this work by demonstrating that very similar VLPs are abundant in a range of tropical coral species, as well as in a tropical zoanthid, and that these VLPs are released to the external environment, especially under thermal stress. Moreover, we previously reported the lytic effect of the medium around heat-degraded FIZ from the temperate sea anemone Anemonia viridis on otherwise unstressed zooxanthellae (Wilson et al. 2001) and have here shown a similar phenomenon with zooxanthellae from the coral Stylophora pistillata. However, the FC data presented here are perhaps the strongest evidence thus far that the VLPs present in corals and their relatives, and in the zooxanthellae associated with them, are viruses. The infection of symbiotic algae by viruses would certainly not be surprising, as numerous free-living marine primary producers, including microalgae (Bratbak et al. 1996, Lawrence et al. 2001, Schroeder et al. 2002, Brussaard 2004a), a wide range of cyanobacteria (Proctor \& Fuhrman 1990, Wilson et al. 1993, Fuller et al. 1998, Suttle 2000, Hewson et al. 2001, McDaniel et al. 2002) and macroalgae (Kapp 1998, Maier \& Muller 1998) are susceptible to viral infections. However, we cannot yet state unequivocally that viruses actively propagate within corals or their symbionts; it will be difficult to state this unless a good in vitro system can be established and perhaps used to develop diagnostic markers for detecting virus infection in natural coral reef systems.

\section{Viral morphology and the application of TEM}

The tail-less, hexagonal VLPs of 40 to $80 \mathrm{~nm}$ diameter seen in the present study are consistent with the shape and size range of numerous VLPs (diameter 40 to $50 \mathrm{~nm}$ ) seen in zooxanthellae from the temperate sea anemone Anemonia viridis (Wilson et al. 2001), and in coral tissue and zooxanthellae of Pavona danai (Wilson et al. 2005). In addition, small tail-less VLPs of only 30 to $40 \mathrm{~nm}$ diameter were also seen in zooxanthellae from P. danai (Wilson et al. 2005). The VLPs in the current study are somewhat smaller and less diffuse in appearance than those seen by Cervino et al. (2004) in zooxanthellae from the coral Montastraea sp, which were 100 to $150 \mathrm{~nm}$ in diameter (J. Cervino, T. Goreau \& R. Hayes pers. comm.). VLPs seen in other, nonsymbiotic dinoflagellates and algae range in diameter from 35 to $390 \mathrm{~nm}$ and are, again, most commonly hexagonal and tail-less (Franca 1976, Sicko-Goad \& Walker 1979, Wolf et al. 2000, Tarutani et al. 2001, Schroeder et al. 2002, Wilson et al. 2002a). The long filamentous VLPs reported here are similar in appearance to numerous plant viruses (van Regenmortel et al. 2000).

No other reports of VLPs in stressed symbiotic Anthozoa or dinoflagellates currently exist. In light of our research, this is more than likely due to the inconspicuous nature of such small particles rather than to their widespread absence, though we have thus far failed to find evidence of viruses in the corals Montipora digitata, Acropora millepora, Pocillopora damicornis and Seriatopora hystrix, or their isolated zooxanthellae, after thermal stress (Davy et al. unpubl. data). Furthermore, the majority of published electron micrographs of zooxanthellae and their hosts involve non-stressed organisms, so it is perhaps not surprising that VLPs have not been more extensively documented. Of note, O'Brien et al. (1984) searched for, but failed to find, evidence of viruses in healthy zooxanthellae and zoochlorellae from the temperate sea anemone Anthopleura xanthogrammica.

While the observation of VLPs in TEM images is strong evidence for viral infection in corals and other reef organisms, there is always concern that TEM images may contain artefacts. For instance, it could be argued that TEM stains or contamination during sample processing may have led to the appearance of unusual particles in thin-sections. This seems unlikely in our work, given the consistency in shape and size of the VLPs and the fact that they were far more numerous in heatshocked samples than in controls. Nevertheless, TEM alone cannot be used to claim that the VLPs in corals are viruses.

\section{Infectivity studies and their role in viral characterisation}

The lysis of non-heat-treated zooxanthellae from Stylophora pistillata by medium from around thermally stressed zooxanthellae suggests that released VLPs may be inducing this lysis. This certainly was the case when similar experiments were carried out using Anemonia viridis and its zooxanthellae (Wilson et al. 2001), as degrading FIZ contained pockets of VLPs. This propagation of the infectious agent without the aid of thermal shock was used to satisfy Koch's postu- 
lates and conclude that zooxanthellae in A. viridis harbour a latent viral infection that is induced by exposure to elevated temperature. Such a conclusion cannot be reached here for $S$. pistillata as TEM did not show VLPs within the inoculated FIZ. A negative result should not be taken as conclusive evidence that viruses were not involved in cell lysis, as comprehensive screening of samples is difficult with TEM, but it does raise the possibility that another factor may have contributed to the lysis of zooxanthellae. One such factor is a toxic agent produced by heat-stressed, degenerating zooxanthellae. Nothing is known about the chemicals released by lysed zooxanthellae, though homogenized cnidarian tissue (which tends to contaminate even the most thoroughly cleaned preparations of zooxanthellae) can occasionally cause rapid lysis of zooxanthellae (Sutton \& Hoegh-Guldberg 1990). Moreover, the production of toxins by both free-living marine dinoflagellates (Turner \& Tester 1997, Klopper et al. 2003) and zooxanthellae (Nakamura et al. $1995 \mathrm{a}, \mathrm{b})$ is well known. Therefore, while inoculation experiments such as the one described in the present paper are useful tools for looking at viral infection cycles, interpretation is hampered by our incomplete biochemical knowledge of the host animal and algal symbionts concerned.

\section{Flow cytometry and the measurement of viral infection}

The recent development of sensitive nucleic acid stains and their use in detecting viruses by flow cytometry has revolutionised the way we identify and, in particular, enumerate viruses in aquatic systems (Marie et al. 1999, Jacquet et al. 2002, Wilson et al. $2002 b$, Brussaard 2004b). The main problem is that the analysis is conducted at the limit of a flow cytometer's detection threshold and, thus, many very small viruses (such as small filamentous RNA viruses) are easily missed.

Our FC data are good evidence that the VLPs observed are indeed viruses. The virus group observed in the first heat shock experiment on Acropora formosa is characteristic of large double-stranded DNA (dsDNA) viruses and has side-scatter and fluorescence properties similar to those of the algal viruses that infect the microalga Emiliania huxleyi (Wilson et al. 2002b). Although many different virus morphotypes were observed in abundance following heat shock of A. formosa, the hexagonal VLPs of 40 to $50 \mathrm{~nm}$ in diameter would be most likely to give this flow cytometry signature, assuming that they are dsDNA viruses. It is tempting to conclude that these viruses were released from a zooxanthella host (i.e. another microalga); how- ever, without conclusive ancillary data it would be imprudent to do so. Unfortunately, the repeat experiment yielded a virus group with very different sidescatter and fluorescence properties. This group perhaps contained the long filamentous VLPs seen in the concurrent TEM analysis, though rigorous testing is required before any conclusions can be drawn and we are currently impeded by the lack of a good in vitro coral or zooxanthellae host/virus system that we can use as a control.

VLPs observed in this study were diverse in morphology, highlighting the key question when interpreting our FC data: To what extent are the particles appearing on the scatter-plots of coral or zooxanthellar origin, as opposed to being bacteriophages or cyanophages from the diverse microbial community, which no doubt inhabits the coral's surface? We are unable to answer this question using flow cytometry. The most frequently observed VLPs by TEM are small, tail-less and hexagonal, i.e. similar in size to those we see regularly inside corals and zooxanthellae, as well as around thin-sections of zoanthid tentacles. These small VLPs are at the detection limit of the flow cytometer, so flow cytometry must be used in conjunction with techniques that can characterise the morphology and molecular features of particles, and thereby clearly establish their identity.

In summary, we have demonstrated VLPs in corals and other cnidarians as well as in their associated zooxanthellae. VLPs of similar size and shape are also seen around heat-shocked corals, though a number of other VLP morphotypes are also seen. While the methods employed have some limitations, taken together our data support the idea that these VLPs are viruses. However, we are still lacking the all-important virus isolate and subsequent genome sequence data to solve this problem conclusively. Once viruses have been identified, work can get under way to establish the precise origins, diversity, propagation mechanisms and environmental triggers of coral viruses. The full molecular characterisation of viruses associated with reef corals is therefore a major step on the way to understanding the role of these pathogens in coral reef health.

Acknowledgements. We thank P. Bond, R. Moate and K. Ryan from the Plymouth Electron Microscope Centre at the University of Plymouth for their assistance. W.H.W. was supported partly by a Marine Biological Association of the UK Research Fellowship funded by grant in aid from the Natural Environmental Research Council (NERC) and partly by the NERCfunded core strategic research programme of Plymouth Marine Laboratory. A.L.D. was supported by an Undergraduate Research Bursary awarded by the Nuffield Foundation to S.K.D. (NUF-URB02). O.H.G. was supported by a grant from the Australian Research Council and the Global Environment Facility (GEF)/World Bank Coral Reef Targeted Research \& Capacity Building Program. 


\section{LITERATURE CITED}

Aeby GS (2003) Corals in the genus Porites are susceptible to infection by a larval trematode. Coral Reefs 22:216

Alker AP, Smith GW, Kim K (2001) Characterization of Aspergillus sydowii (Thom et Church), a fungal pathogen of Caribbean sea fan corals. Hydrobiologia 460:105-111

Barber RT, Hilting AK, Hayes ML (2001) The changing health of coral reefs. Hum Ecol Risk Assess 7:1255-1270

Bergh O, Borsheim KY, Bratbak G, Heldal M (1989) High abundance of viruses found in aquatic environments. Nature 340:467-468

Blank RJ (1987) Cell architecture of the dinoflagellate Symbiodinium sp. inhabiting the Hawaiian stony coral Montipora verrucosa. Mar Biol 94:143-155

Bratbak G, Wilson WH, Heldal M (1996) Viral control of Emiliania huxleyi blooms. J Mar Syst 9:75-81

Bruno JF, Petes LE, Harvell CD, Hettinger A (2003) Nutrient enrichment can increase the severity of coral diseases. Ecol Lett 6:1056-1061

Brussaard CPD (2004a) Viral control of phytoplankton populations - a review. J Eukaryot Microbiol 51:125-138

Brussaard CPD (2004b) Optimization of procedures for counting viruses by flow cytometry. Appl Environ Microbiol 70:1506-1513

Brussaard CPD, Marie D, Bratbak G (2000) Flow cytometric detection of viruses. J Virol Methods 85:175-182

Bythell JC, Douglas AE, Sharp VA, Searle JB, Brown BE (1997) Algal genotype and photoacclimatory responses of the symbiotic alga Symbiodinium in natural populations of the sea anemone Anemonia viridis. Proc R Soc Lond B Biol Sci 264:1277-1282

Cervino JM, Hayes R, Goreau TJ, Smith GW (2004) Zooxanthellae regulation in yellow blotch/band and other coral diseases contrasted with temperature related bleaching: in situ destruction vs expulsion. Symbiosis 37:63-85

Chen F, Suttle CA, Short SM (1996) Genetic diversity in marine algal virus communities as revealed by sequence analysis of DNA polymerase genes. Appl Environ Microbiol 62:2869-2874

Cooney RP, Pantos O, Le Tissier MDA, Barer MR, O'Donnell AG, Bythell JC (2002) Characterization of the bacterial consortium associated with black band disease in coral using molecular microbiological techniques. Environ Microbiol 4:401-413

Douglas AE (2003) Coral bleaching - how and why? Mar Pollut Bull 46:385-392

Edgar RS, Lielausis I (1964) Temperature sensitive mutants of phage T4D: their isolation and genetic characterisation. Genetics 49:649-662

Franca S (1976) On the presence of virus-like particles in the dinoflagellate Gyrodinium resplendens (Hulburt). Protistologica 12:425-430

Fuhrman JA (1999) Marine viruses and their biogeochemical and ecological effects. Nature 399:541-548

Fuller NJ, Wilson WH, Joint IR, Mann NH (1998) Occurrence of a sequence in marine cyanophages similar to that of T4 g20 and its application to PCR-based detection and quantification techniques. Appl Environ Microbiol 64:2051-2060

Geiser DM, Taylor JW, Ritchie KB, Smith GW (1998) Cause of sea fan death in the West Indies. Nature 394:137-138

Guillard RRL (1975) Culture of phytoplankton for feeding marine invertebrates. In: Smith WL, Chanley MH (eds) Culture of marine invertebrate animals. Plenum Press, New York, p 29-60

Harvell CD, Kim K, Burkholder JM, Colwell RR and 9 others
(1999) Emerging marine diseases-climate links and anthropogenic factors. Science 285:1505-1510

Harvell CD, Kim K, Quirolo C, Weir J, Smith G (2001) Coral bleaching and disease: contributors to 1998 mass mortality in Briareum asbestinum (Octocorallia, Gorgonacea). Hydrobiologia 460:97-104

Harvell CD, Mitchell CE, Ward JR, Altizer S, Dobson AP, Ostfeld RS, Samuel MD (2002) Climate warming and disease risks for terrestrial and marine biota. Science 296:2158-2162

Hennes KP, Suttle CA, Chan AM (1995) Fluorescently labeled virus probes show that natural virus populations can control the structure of marine microbial communities. Appl Environ Microbiol 61:3623-3627

Hewson I, O'Neil JM, Dennison WC (2001) Virus-like particles associated with Lyngbya majuscula (Cyanophyta; Oscillatoriacea) bloom decline in Moreton Bay, Australia. Aquat Microb Ecol 25:207-213

Hoegh-Guldberg O (2004) Coral reefs in a century of rapid environmental change. Symbiosis 37:1-31

Israely T, Banin E, Rosenberg E (2001) Growth, differentiation and death of Vibrio shiloi in coral tissue as a function of seawater temperature. Aquat Microb Ecol 24:1-8

Jacquet S, Bratbak G (2003) Effects of ultraviolet radiation on marine virus-phytoplankton interactions. FEMS Microbiol Ecol 44:279-289

Jacquet S, Heldal M, Iglesias-Rodriguez D, Larsen A, Wilson WH, Bratbak G (2002) Flow cytometric analysis of an Emiliana huxleyi bloom terminated by viral infection. Aquat Microb Ecol 27:111-124

Jiang SC, Paul JH (1998) Gene transfer by transduction in the marine environment. Appl Environ Microbiol 64:2780-2787

Kapp M (1998) Viruses infecting marine brown algae. Virus Genes 16:111-117

Klopper S, Scharek R, Gerdts G (2003) Diarrhetic shellfish toxicity in relation to the abundance of Dinophysis spp. in the German Bight near Helgoland. Mar Ecol Prog Ser 259:93-102

Kushmaro A, Banin E, Loya Y, Stackebrandt E, Rosenberg E (2001) Vibrio shiloi sp nov, the causative agent of bleaching of the coral Oculina patagonica. Int J Syst Evol Microbiol 51:1383-1388

Lawrence JE, Chan AM, Suttle CA (2001) A novel virus (HaNIV) causes lysis of the toxic bloom-forming alga Heterosigma akashiwo (Raphidophyceae). J Phycol 37: 216-222

Leadbeater BSC, Harris EA, Wood KR (1998) Marine algal viruses. In: Le Gal Y, Muller-Feuga A (eds) Marine microorganisms for industry. Actes de colloques, Éditions Ifremer, Plouzane, p 7-17

Lesser MP (2004) Experimental biology of coral reef ecosystems. J Exp Mar Biol Ecol 300:217-252

Maier I, Muller DG (1998) Virus binding to brown algal spores and gametes visualized by DAPI fluorescence microscopy. Phycologia 37:60-63

Malin G, Wilson WH, Bratbak G, Liss PS, Mann NH (1998) Elevated production of dimethylsulfide resulting from viral infection of cultures of Phaeocystis pouchetii. Limnol Oceanogr 43:1389-1393

Marie D, Brussaard CPD, Thyrhaug R, Bratbak G, Vaulot D (1999) Enumeration of marine viruses in culture and natural samples by flow cytometry. Appl Environ Microbiol 65:45-52

McDaniel L, Houchin LA, Williamson SJ, Paul JH (2002) Plankton blooms-lysogeny in marine Synechococcus. Nature 415:496-496

Nakamura H, Asari T, Fujimaki K, Maruyama K, Murai A, Ohizumi Y, Kan Y (1995a) Zooxanthellatoxin-B, vasocon- 
strictive congener of zooxanthellatoxin-A from a symbiotic dinoflagellate Symbiodinium sp. Tetrahedron Lett 36: 7255-7258

Nakamura H, Asari T, Murai A, Kan Y, Kondo T, Yoshida K, Ohizumi Y (1995b) Zooxanthellatoxin-A, a potent vasoconstrictive 62-membered lactone from a symbiotic dinoflagellate. J Am Chem Soc 117:550-551

Nowak R (2004) Sewage nutrients fuel coral disease. New Sci 181:12-13

O'Brien TL, Macleod R, Maclean MC (1984) Absence of lytic virus in 2 species of symbiotic algae within the sea anemone Anthopleura xanthogrammica (Coelenterata: Anthozoa). Trans Am Microsc Soc 103:228-232

Porter JW, Dustan P, Jaap WC, Patterson KL, Kosmynin V, Meier OW, Patterson ME, Parsons M (2001) Patterns of spread of coral disease in the Florida Keys. Hydrobiologia 460:1-24

Proctor LM, Fuhrman JA (1990) Viral mortality of marine bacteria and cyanobacteria. Nature 343:60-62

Richardson LL, Kuta KG (2003) Ecological physiology of the black band disease cyanobacterium Phormidium corallyticum. FEMS Microbiol Ecol 43:287-298

Savage AM, Goodson MS, Visram S, Trapido-Rosenthal H, Wiedenmann J, Douglas AE (2002) Molecular diversity of symbiotic algae at the latitudinal margins of their distribution: dinoflagellates of the genus Symbiodinium in corals and sea anemones. Mar Ecol Prog Ser 244:17-26

Scanlan DJ, Wilson WH (1999) Application of molecular techniques to addressing the role of $\mathrm{P}$ as a key effector in marine ecosystems. Hydrobiologia 401:149-175

Schroeder DC, Oke J, Malin G, Wilson WH (2002) Coccolithovirus (Phycodnaviridae): characterisation of a new large dsDNA algal virus that infects Emiliania huxleyi. Arch Virol 147:1685-1698

Schroeder DC, Oke J, Hall M, Malin G, Wilson WH (2003) Virus succession observed during an Emiliania huxleyi bloom. Appl Environ Microbiol 69:2484-2490

Sicko-Goad L, Walker G (1979) Viroplasm and large viruslike particles in the dinoflagellate Gymnodinium uberrimum. Protoplasma 99:203-210

Sutherland KP, Porter JW, Torres C (2004) Disease and immunity in Caribbean and Indo-Pacific zooxanthellate corals. Mar Ecol Prog Ser 266:273-302

Suttle CA (1994) The significance of viruses to mortality in

Submitted: September 15, 2004; Accepted: May 25, 2005 aquatic microbial communities. Microb Ecol 28:237-243

Suttle CA (2000) Cyanophages and their role in the ecology of cyanobacteria. In: Whitton BA, Potts M (eds) The ecology of cyanobacteria: their diversity in time and space. Kluwer Academic Publishers, Boston, MA

Sutton DC, Hoegh-Guldberg O (1990) Host-zooxanthella interactions in 4 temperate marine invertebrate symbioses - assessment of effect of host extracts on symbionts. Biol Bull (Woods Hole) 178: 175-186

Tarutani K, Nagasaki K, Itakura S, Yamaguchi M (2001) Isolation of a virus infecting the novel shellfish-killing dinoflagellate Heterocapsa circularisquama. Aquat Microb Ecol 23:103-111

Turner JT, Tester PA (1997) Toxic marine phytoplankton, zooplankton grazers, and pelagic food webs. Limnol Oceanogr 42:1203-1214

van Regenmortel MHV, Fauquet CM, Bishop DHL, Carstens EB and 7 others (eds) (2000) Virus taxonomy: Seventh Report of the International Committee on Taxonomy of Viruses. Academic Press, San Diego, CA

Wilson WH, Chapman DM (2001) Observation of virus-like particles in thin sections of the plumose anemone, Metridium senile. J Mar Biol Assoc UK 81:879-880

Wilson WH, Joint IR, Carr NG, Mann NH (1993) Isolation and molecular characterisation of 5 marine cyanophages propagated on Synechococcus sp. strain WH7803. Appl Environ Microbiol 59:3736-3743

Wilson WH, Francis I, Ryan K, Davy SK (2001) Temperature induction of viruses in symbiotic dinoflagellates. Aquat Microb Ecol 25:99-102

Wilson WH, Tarran GA, Schroeder D, Cox M, Oke J, Malin G (2002a) Isolation of viruses responsible for the demise of an Emiliania huxleyi bloom in the English Channel. J Mar Biol Assoc UK 82:369-377

Wilson WH, Tarran GA, Zubkov MV (2002b) Virus dynamics in a coccolithophore-dominated bloom in the North Sea. Deep-Sea Res Part II 49:2951-2963

Wilson WH, Dale AL, Davy JE, Davy SK (2005) An enemy within? Observations of virus-like particles in reef corals. Coral Reefs 24: 145-148

Wolf S, Muller DG, Maier I (2000) Assembly of a large icosahedral DNA virus, MclaV-1, in the marine alga Myriotrichia clavaeformis (Dictyosiphonales, Phaeophyceae). Eur J Phycol 35:163-171

Proofs received from author(s): December 23, 2005 